\title{
PRINCIPAL TRANSFORMATIONAL LEADERSHIP IN HIGH SCHOOL OF CENTRAL KALIMANTAN
}

\author{
Asti Putri Kartiwi ${ }^{\bowtie}$ \\ 1,2 Department of Education, Faculty of Education, University of Bengkulu, Indonesia \\ $\bowtie$ astiputri@unib.com
}

\begin{abstract}
Transformational leadership is considered to play an important role in improving the quality of service because a transformational leader can foster a strong commitment between staff and the organization, as well as staff and teammates where they are willing to work beyond their own abilities for the organization and become potential partners for the organization. This study aims to look at the condition of principals' transformational leadership in state high schools in Central Kalimantan Province with indicators to be seen including Idealized Influenced, Inspiration Motivation, and Intellectual Stimulation. The method used is descriptive quantitative with the teacher as the respondent. Based on the results of the study it is known that the transformational leadership condition of the headmaster of state high schools in the province of Central Kalimantan is in the sufficient category. Suggestions and recommendations are given to school principals to increase intellectual stimulation to subordinates, especially teachers at the school.
\end{abstract}

Keywords: Transformational leadership; Principal; schools

\section{INTRODUCTION}

Leadership reflects an assumption concerning a process of social influence, which was deliberately run by a person against another person to manage activities and relationships within a group or organization. (Ruben and Gigliotti, 2016). "Someone" is meant in this case is a leader in a group or organization.

Success to obtain a good quality of education depends on the strong leadership of each principal. (Day and Sammons,2016), (Leithwood and Hopkins, 2008). Successful leaders are those whose organizations have achieved their goals. A success of principals' leadership in managing educational organizations is influenced by the ability to carry out planning, organizing, directing and monitoring activities for each operational unit of education. (1) roles related to personal relationships, including the principal as a symbol of the organization, leaders, and relationship, (2) roles related to information, include the principal as the person who distributes, information to all organizational environments, and (3) the role that relating to decision making, which includes the principal as the provider of all resources, and the negotiator. (Pont \& Moorman, 2008), (Elmore, 2000)

On the other hand, Lakomski (2001) in her article "Leadership Paradoxes and New Direction" suggests fourteen roles of principal : (1) the principal as business 
manager, (2) the principal as the manager of the office, (3) the principal as an administrator, (4) the principal as professional leader, (5) the principal as organizers, (6) the principal as a motivator or staff mobilizer, (7) the principal as a supervisor, (8) the principal as a curriculum consultant, (9) the principal as an educator, (10) the principal as a psychologist, (11) the principal schools as school authorities, (12) principals as good executives, (13) principals as school relations officers with the community, and (14) principals as communityleaders.

Of the fourteen roles, can be classified into two, namely the principal as an education administrator and as an education supervisor.

The transformational leadership approach was originally conceived. James MacGregor Burns in Bass and Riggio (2008) distinguishes two types of leadership, namely transactional leadership and its opponent, transformational leadership. Transactional patterned leaders are those who lead through social exchange. For example, politicians lead by "exchanging" one thing for another, such as voting, or subsidizing campaign contributions. Transactional-style business leaders offer financial rewards for productivity or don't reward rewards for lack of productivity. Meanwhile, transformational leaders are those who stimulate and inspire their followers, both to achieve something unusual and, in the process, develop their own leadership capacity. Transformational leaders help their followers to develop and make them new leaders by responding to the individual needs of followers. They empower followers by aligning the larger goals of individual followers, leaders, groups and organizations. A leader is said to be transformationally measured by the level of trust, obedience, admiration, loyalty and respect for his followers. The followers of transformational leaders are always motivated to do even better to achieve organizational goals.

Transformational Leadership is related to charismatic leadership. Charisma is a very important part of Transformational Leadership, but it is not enough to carry out the transformation process. The most striking difference is that transformational leaders try to give power according to their respective authority capacities and empower subordinates, but on charismatic leadership, leaders may try to keep their followers weak to always feel dependent and obedient to them. Transformational leadership can change followers beyond expected performance, as they are able to achieve follower satisfaction and commitment to groups or organizations (Bass and Riggio,2008).

Using transformational models is proven in research by Avolio and Yammarino (2002) that everysector and the situation of the use of the transformational leadership model is important. At first, transformational leadership is widely used in situations or military organizations because it has proven using transformational leadership, leaders also must prepare subordinates to become leaders in the future.

The leader inspires subordinates with challenges and influences, providing understanding and understanding. Intellectually the leader provides excitement for subordinates' understanding of their abilities. 
Each component by Bass and Alovio (2008) is made using a measurement scale MLQ or Multifactor Leadership Questionnaire. Component description of MLQ is:

a. Idealized Influence, Transformational leaders behave like role models or models for their followers.

b. Inspirational Motivation, The leader must be able to act in a way that can motivate and inspire around him by providing understanding and challenge to subordinates.

c. Intellectual Stimulation, Leaders can provide stimulation/stimulation to subordinates to be creative, innovative by giving questions that are assumptions, packaging problems in new ways, making new approaches to problems. (,Bass dan Riggio, 2008).

Based on the research interests of the theories of transformational leadership principals of the researchers wanted to know transformational leadership principals in high schools in Central Kalimantan province.

The object of research is the state high schools in Central Kalimantan province because the province of Central Kalimantan is a developing province. Where an increase in the quality of education is one of the main programs of local governments.

\section{METHOD}

the approach used in this research is descriptive quantitative. This method aims to analyze the data obtained from the research sample to then take meaning from the results of the data processing. (Elliott and Timulak 2005), (Maxwell, 1992)
The location of the study was Central Kalimantan Province with the subject under study was the headmaster of a state high school with school A accreditation in the province of Central Kalimantan.

The population of this study is the state high school teachers who have accreditation $A$ in Central Kalimantan province as many as 596 people and take a sample of 196. The reason the researchers took the research location in the accredited A public high school is that schools with accreditation A are selected schools that are considered to have quality standards best in the province of Central Kalimantan.

Assessment indicators include the dimensions of Idealized Influenced, Inspiration Motivation, and Intellectual Stimulation.

Data collection techniques using a closed questionnaire. Based on the questionnaire the average respondent's response will be calculated and compared with the following table to be classified into categories.

Table

Comparative average responder

\begin{tabular}{|c|c|c|}
\hline No. & Score & Criteria \\
\hline 1 & $1,00-1,80$ & Very Low \\
\hline 2 & $1,81-2,60$ & Low \\
\hline 3 & $2,61-3,40$ & Fair \\
\hline 4 & $3,41-4,20$ & High \\
\hline 5 & $4,21-5,00$ & Very High \\
\hline
\end{tabular}

\section{RESULTS}

Based on the results of the questionnaire obtained the following results 
Tabel

On average respondents to the transformational leadership principals.

the results of the work carried out, Encouraging teachers and administrative staff to put the interests of groups firstrather than personal interests. And further increasing the needs of teachers and higher staff such as self-esteem and selfactualization of each other. So as to create a great sense of respect for yourself, colleagues and superiors

\section{DISCUSSION}

Based on the results of the average response of respondents, in general, the principal's transformational leadership is in the sufficient category. While specifically, the dimensions of the Idealized Influenced are in the moderate category, Inspiration Motivation is in the moderate category and Intellectual Stimulation is in a low category.

Thus the question arises why the principal aspects of Intellectual Stimulation on SMA accredited in Central Kalimantan province could be in the low condition? This means that the principal has not been able to provide stimuli to be creative, innovative by giving questions that are assumptions, packaging problems in new ways, making new approaches to problems. Build the creativity of his subordinates to be able to minimize mistakes.

The inability of transformational leaders in stimulating teachers and staff to be always creative and innovative is due to the lack of active communication between superiors and subordinates. This is the same as stated by Bass and Riggio (2008) That leaders who can transform the vision and mission of the school must be able to encourage teachers and administrative staff to be more aware of the importance of

\section{CONCLUSION}

Based on the results of the above study concluded that the transformational leadership of school principals in state high schools in Central Kalimantan Province was in a sufficient category. The school principal's suggestion is to continue to improve communication skills so as to create a good relationship with teachers so that they can increase the motivation of teachers in carrying out work.

\section{REFERENCES}

Bass, B. M. dan Riggio, R. E. (2008). Transformational Leadership. Mahwah, New Jersey: Lawrence Erlbaum Associates, Inc.

Lakomski, G. (2001). Organizational change, leadership, and learning: culture as cognitive process. International Journal of Educational Management, 15(2), 68-77.

Ruben, B. D., \& Gigliotti, R. A. (2016). Leadership as social influence: An expanded view of leadership communication theory and practice. Journal of Leadership \& Organizational Studies, 23(4), 467-479.

Day, C., Gu, Q., \& Sammons, P. (2016). The impact of leadership on student outcomes: How successful school leaders use transformational and instructional strategies to make a difference.Educational 
Administration Quarterly, 52 (2), 221-258.

Leithwood, K., Harris, A., \& Hopkins, D. (2008). Seven strong claims about successful school leadership.School leadership and management, 28(1), 27-42.

Pont, B., Nusche, D., \& Moorman, H. (2008). Improving school leadership, Volume 1: Policy and practice. Australia: OECD Publications. Available online also at: https://www. oecd. org/edu/school/44374889. pdf [accessed in Makassar, Indonesia: October 9, 2016].

Elmore, R. F. (2000). Building a new structure for school leadership. Albert Shanker Institute.

Avolio, Bruce. J., dan Yammarino, Francis.J. (2002). Transformational and Charismatic Leadership The Road Ahead Volume 2. JAl: PressINC.

Elliott, R., \& Timulak, L. (2005). Descriptive and interpretive approaches to qualitative research. A handbook of research methods for clinical and health psychology, 1 (7), 147-159.

Maxwell, J. (1992). Understanding and validity in qualitative research.Harvard educational review, 62 (3), 279 
